\title{
Efek Minuman Keras Oplosan terhadap Perubahan Histopatologi Organ Renal Tikus Wistar Jantan
}

\section{(The Effect of Mixed Liquor toward the Histopathological Change of Kidney in Male Wistar)}

\author{
Made Masagung Kawiartha, Rena Normasari, Bagus Hermansyah \\ Fakultas Kedokteran Universitas Jember \\ Jln. Kalimantan 37, Jember 68121 \\ email: rena_normasari@unej.ac.id
}

\begin{abstract}
Mixed liquor is a liquor mixed with other substances, mainly ethanol and methanol. Mixed liquor can cause kidney destruction. The aim of this study was to investigate the effect of mixed liquor toward kidney's microscopic and macroscopically changes. This study used 24 rats which were divided into 4 groups consist of 1 control group and 3 experimental groups. The first, second, and third experimental groups were given ethanol 1,296m//2 days; methanol 0,2592m//2days and aquades 1,4448m//2 days for 5 days; 11 days and 17 days, respectively. Afterward rats were terminated and the right kidney mass was measured. The kidney tissue was prepared for histological examination and the number of necrotic cell was calculated. According to Kruskal Wallis test, kidney mass was not significantly different $(p>\alpha)$ while total necrotic cells was significantly different $(p<\alpha)$. This study showed that rats induced with mixed liquor for 5,11 , and 17 days resulted in kidney microscopically change.
\end{abstract}

Keywords: kidney macroscopically change, mixed liquor, necrotic cell

\begin{abstract}
Abstrak
Minuman keras oplosan merupakan minuman keras yang telah dicampur berbagai zat. Etanol dan metanol merupakan zat utama yang terkandung dalam minuman keras oplosan tersebut. Minuman keras oplosan dapat menyebabkan kerusakan ginjal. Sehingga tujuan dari penelitian ini adalah untuk mengetahui dampak konsumsi minuman keras oplosan terhadap perubahan mikroskopis dan makroskopis ginjal. Penelitian ini menggunakan 24 tikus yang terbagi dalam 1 kelompok kontrol dan 3 kelompok perlakuan. Kelompok perlakuan 1 diberikan etanol 1,296ml, metanol $0,2592 \mathrm{ml}$ dan aquades $1,4448 \mathrm{ml}$ tiap 2 hari sekali selama 5 hari, perlakuan 2 selama 11 hari dan perlakuan 3 selama 17 hari. Kemudian tikus diterminasi dan dihitung berat ginjal kanan. Setelah itu ginjal kanan tikus dibuat preparat histopatologi dan dihitung jumlah sel nekrosis tiap lima lapang pandang. Berdasarkan uji Kruskal Wallis didapatkan nilai signifikansi perubahan berat ginjal sebesar 0,118 $(p>\alpha)$ sedangkan perubahan jumlah sel nekrosis sebesar 0,000 $(p<\alpha)$. Sehingga berdasarkan hasil tersebut dapat disimpulkan bahwa tikus yang diinduksi minuman keras oplosan selama 5, 11 dan 17 hari dapat menyebabkan perubahan mikroskopis ginjal.
\end{abstract}

Kata kunci: minuman keras oplosan, perubahan makroskopis ginjal, sel nekrosis 


\section{Pendahuluan}

Minuman keras oplosan merupakan minuman beralkohol tradisional dengan kandungan etanol yang tidak terlalu tinggi [1]. Sayangnya sekarang minuman keras oplosan tersebut sudah dicampur dengan zat-zat lain yang dapat semakin membahayakan tubuh, salah satunya adalah metanol. Metanol digunakan oleh masyarakat karena memiliki efek sedatif yang sama dengan etanol namun dengan harga yang lebih murah. Sayangnya metanol memiliki dampak yang lebih buruk terhadap kesehatan. Salah satu dampak buruk tersebut adalah kerusakan ginjal. Pada tahun 2011 sebanyak 22.304 warga Indonesia menderita gangguan ginjal dan sebanyak 6.951 warga harus menjalani hemodialisis secara rutin [2]. Maka dari itu, jika masyarakat tetap mengkonsumsi minuman keras oplosan, akan semakin banyak penderita gagal ginjal di Indonesia.

Minuman keras oplosan memiliki kandungan utama berupa etanol dan metanol. Etanol merupakan larutan jernih, berbau khas, manis namun pada konsentrasi tertentu dapat menyebabkan kerusakan kulit. Metabolisme etanol mayoritas terjadi di hepar. Etanol dimetabolisme menjadi asetaldehid dengan bantuan alkohol dehidrogenase, kemudian dimetabolisme lagi menjadi asetat dengan bantuan aldehid dehidrogenase [3]. Metabolit etanol ini yang nantinya akan menyebabkan gangguan pada ginjal. Gangguan ginjal tersebut adalah tubular nekrosis akut, dilatasi tubulus dan perubahan epitel tubulus menjadi pipih [4].

Metanol dikenal sebagai zat yang memiliki sifat menyerupai etanol namun lebih berbahaya dibanding etanol. Metanol mayoritas akan dimetabolisme di hepar. Metanol akan diubah menjadi formaldehid, kemudian diubah lagi menjadi asam format. Asam format ini yang nantinya dapat menyebabkan kerusakan pada ginjal. Kerusakan tersebut salah satunya adalah perubahan hidropik tubulus proksimal [5].

Tujuan dari penelitian ini adalah untuk mengetahui dampak konsumsi minuman keras oplosan selama 5, 11 dan 17 hari terhadap perubahan mikroskopis dan makroskopis organ ginjal tikus wistar jantan. Dari penelitian ini diharapkan dapat diketahui adanya perubahan makroskopis berupa perubahan berat ginjal dan mikroskopis berupa peningkatan jumlah sel ginjal yang mengalami nekrosis pada tikus yang diinduksi etanol dan metanol.

\section{Metode Penelitian}

Penelitian ini berlangsung selama 40 hari dan telah mendapat persetujuan dari Komisi Etik Fakultas Kedokteran Universitas Jember. Tempat penelitian ini di UPT Pengujian Sertifikasi Mutu Barang Lembaga Tembakau Jember untuk memperoleh kadar etanol dan metanol, Fakultas Kedokteran Gigi Universitas Jember untuk pemeliharan sampel dan mengukur berat ginjal serta Lab Patologi Anatomi Fakultas Kedokteran Universitas Jember untuk pengamatan preparat histopatologi ginjal.

Penelitian diawali dengan menentukan kadar etanol dan metanol yang ditemukan di UPT Pengujian Sertifikasi Mutu Barang Lembaga Tembakau Jember dan didapatkan kadar etanol sebesar $20 \%$ dan metanol $40 \%$. Berdasarkan kadar tersebut dapat ditentukan dosis etanol dan metanol yang diberikan kepada tikus. Etanol yang diberikan pada tikus sebanyak 1,296ml/2hari; metanol sebanyak $0,2592 / 2$ hari dan aquades sebanyak $1,4448 \mathrm{ml} / 2$ hari.

Penelitian ini menggunakan 24 tikus yang dibagi menjadi 4 kelompok, yaitu kelompok kontrol dan 3 kelompok perlakuan. Kelompok perlakuan 1 , perlakuan 2 dan perlakuan 3 secara berturut-turut diinduksi etanol, metanol dan aquades selama 5, 11 dan 17 hari. Setelah itu tikus diterminasi, dihitung berat ginjal kanan dan dibuat preparat histopatologi. Preparat histopatologi dibentuk dengan menggunakan metode parafin dan pewarnaan $\mathrm{HE}$.

Setiap preparat histopatologi ginjal dihitung jumlah sel yang mengalami nekrosis dalam lima lapang pandang. Data perubahan berat ginjal dan jumlah sel nekrosis diuji dengan menggunakan analisis data Kruskal Wallis dan uji lanjutan Mann Whitney.

\section{Hasil Penelitian}

Berdasarkan pengamatan berat ginjal, dapat diketahui berat ginjal kanan kelompok kontrol sebesar 0,411 $\pm 0,029 \mathrm{~g} / 100 \mathrm{~g}$ berat badan tikus (BB); perlakuan 1 sebesar $0,429 \pm 0,001 \mathrm{~g} / 100 \mathrm{~g} \mathrm{BB}$; perlakuan 2 sebesar $0,459 \pm 0,052 \mathrm{~g} / 100 \mathrm{~g}$ BB dan perlakuan 3 sebesar $0,464 \pm 0,055 \mathrm{~g} / 100 \mathrm{~g} B \mathrm{BB}$.

Hasil pengamatan berat ginjal tersebut diuji menggunakan Kruskal Wallis. Berdasarkan analisis data tersebut, didapatkan nilai signifikansi $(p)$ sebesar 0,118. 
Tabel 1. Perubahan berat ginjal kanan

\begin{tabular}{cc}
\hline Kelompok & $\begin{array}{c}\text { Berat ginjal }(\mathrm{g} / 100 \mathrm{~g} \text { berat } \\
\text { badan) }(\mathrm{X} \pm \mathrm{SD})\end{array}$ \\
\hline Kontrol & $0,411 \pm 0,029$ \\
\hline Perlakuan 1 & $0,429 \pm 0,001$ \\
\hline Perlakuan 2 & $0,459 \pm 0,052$ \\
\hline Perlakuan 3 & $0,464 \pm 0,055$ \\
\hline
\end{tabular}

Berdasarkan pengamatan sel nekrosis ginjal, dapat diketahui rata-rata jumlah sel nekrosis tiap lapang pandang pada kelompok kontrol adalah $8 \pm 3$ sel, perlakuan 1 sebanyak $43 \pm 2$ sel, perlakuan 2 sebanyak $82 \pm 5$ sel dan perlakuan 3 sebanyak $122 \pm 11$ sel.

Tabel 2. Jumlah sel nekrosis

\begin{tabular}{cc}
\hline Kelompok & $\begin{array}{c}\text { Jumlah sel nekrosis tiap } \\
\text { lapang pandang }(\mathrm{X}+\mathrm{SD})\end{array}$ \\
\hline Kontrol & $8 \pm 3$ \\
\hline Perlakuan 1 & $43 \pm 2$ \\
\hline Perlakuan 2 & $82 \pm 5$ \\
\hline Perlakuan 3 & $122 \pm 11$ \\
\hline
\end{tabular}

Selain nekrosis, dapat ditemukan juga kerusakan ginjal lainnya. Pada kelompok P1 dapat diketahui adanya granular cast dan pelepasan epitel tubulus ke lumen. Kelompok P2 dapat diketahui adanya degenerasi hidropik dan granular cast. Sedangkan pada kelompok P3 dapat diketahui adanya granular cast.

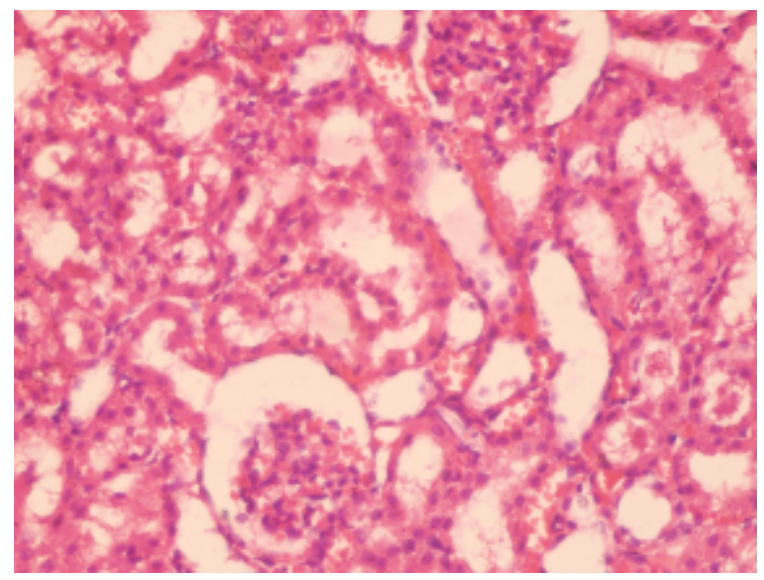

Gambar 1. Histopatologi ginjal kelompok kontrol. Didapatkan tanda kerusakan ginjal yang minimal.

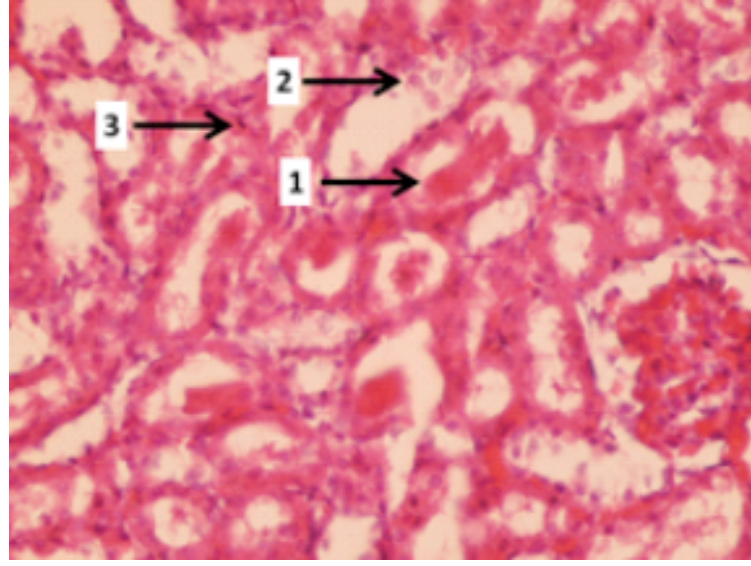

Gambar 2. Histopatologi ginjal kelompok 1. (1) granular cast, (2) epitel tubulus lepas menuju lumen dan (3) sel piknotik.

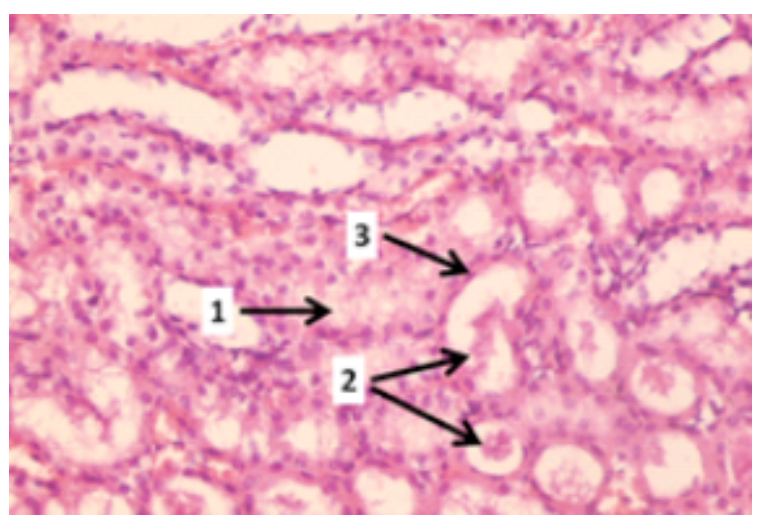

Gambar 3. Histopatologi ginjal kelompok 2. (1) degenerasi hidropik, (2) granular cast dan (3) epitel tubulus menjadi pipih

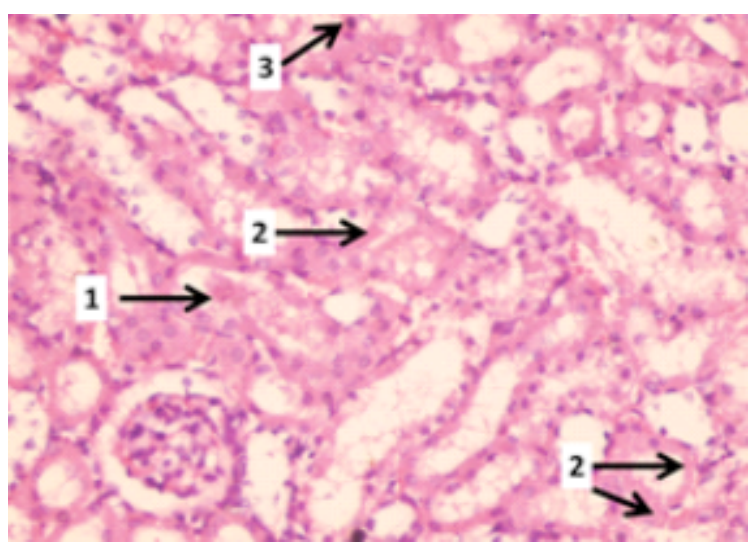

Gambar 4. Histopatologi ginjal kelompok 3. (1) granular cast, (2) sel kariolisis dan (3) sel piknotik 
Hasil pengamatan jumlah sel nekrosis diuji menggunakan Kruskal Wallis. Berdasarkan analisis data tersebut, didapatkan nilai signifikasi (p) sebesar 0,000. Kemudian analisis data dilanjutkan menggunakan uji lanjutan Mann Whitney. Berdasarkan uji lanjutan Mann Whitney didapatkan nilai signifikan ( $p$ ) dari keempat kelompok tersebut sebesar 0,004.

\section{Pembahasan}

Berdasarkan hasil penelitian, rata-rata berat ginjal antara kelompok kontrol, P1, P2, dan P3 mengalami peningkatan. Namun berdasarkan analisis data, perubahan berat ginjal antara kelompok kontrol, P1, P2 dan P3 tidak signifikan. Hal ini terjadi karena beberapa tikus tidak mengalami peningkatan berat ginjal yang signifikan dibandingkan dengan tikus lain dalam kelompok yang sama.

Menurut Kumar (2007) jika organ mengalami degenerasi atau jejas reversibel, organ tersebut menjadi tampak pucat, terjadi peningkatan turgor, dan terjadi peningkatan berat [6,p26]. Namun pada penelitian ini tidak terjadi peningkatan berat ginjal yang signifikan. Hal yang sama terjadi pada penelitian Brzoska (2001), Dinu (2005) dan Ojeda (2012). Menurut Brzoska (2001) tikus yang diinduksi etanol 10\% selama 12 minggu tidak mengalami peningkatan berat ginjal yang signifikan[7]. Selain itu menurut Ojeda (2012) tidak terdapat perbedaan berat ginjal yang bermakna antara tikus yang diinduksi dengan etanol $30 \%$ selama 2 bulan dengan tikus kontrol normal [8]. Bahkan menurut Dinu (2005) tikus yang diinduksi etanol 95\% dengan dosis $2 \mathrm{~g} / \mathrm{kgBB}$ selama $30 \mathrm{ming}$ u tidak menunjukkan adanya peningkatan berat ginjal yang signifikan dibandingkan dengan tikus kelompok kontrol normal [9].

Berdasarkan hasil pengamatan sel tubulus ginjal menggunakan mikroskop pembesaran 400x dapat diketahui bahwa kelompok kontrol memiliki tingkat kerusakan paling rendah. Meskipun kelompok kontrol tidak mendapat perlakuan, ternyata menunjukkan adanya kerusakan sel ginjal yang minimal. Hal yang sama terjadi pada penelitian Amalina (2013). Menurut Amalina (2013) tikus percobaan yang tidak diberi perlakuan tetap dapat menunjukkan adanya kerusakan sel ginjal [10]. Hal ini karena terjadi perubahan pada lingkungan tikus yang sangat berpengaruh terhadap pola sikap dan perilaku.

Gambaran histopatologi ginjal kelompok P1, P2 dan P3 menunjukkan adanya kerusakan yang lebih banyak dibandingkan kelompok kontrol. Hal ini menunjukkan bahwa konsumsi minuman keras oplosan kerusakan sel ginjal. Hasil penelitian ini sesuai dengan penelitian sebelumnya oleh Brzoska pada tahun 2003. Menurut Brzoska (2003) tikus yang diinduksi etanol $10 \%$ selama 12 minggu menunjukkan adanya tanda-tanda kerusakan ginjal. Kerusakan tersebut berupa hipertrofi epitel tubulus, degenerasi epitel tubulus dengan infiltrasi sel mononukleus, dan dilatasi glomerulus [7]. Selain itu menurut studi kasus oleh Verhelst (2004) menunjukkan adanya tanda-tanda gangguan ginjal akut atau kerusakan ginjal pada manusia yang mengalami intoksikasi akibat metanol [5].

\section{Simpulan dan Saran}

Berdasarkan hasil penelitian, dapat disimpulkan bahwa konsumsi minuman keras oplosan selama 5, 11 dan 17 hari tidak dapat menyebabkan perubahan makroskopis atau perubahan berat ginjal namun dapat menyebabkan perubahan mikroskopis ginjal.

Saran yang dapat diberikan oleh peneliti antara lain, perlu adanya penelitian lebih lanjut mengenai dampak minuman keras oplosan terhadap perubahan mikroskopik ginjal dengan menggunakan pewarnaan yang lebih spesifik dan perlu adanya penelitian lebih lanjut mengenai cara mengurangi dampak buruk minuman keras oplosan terhadap ginjal.

\section{Daftar Pustaka}

[1] Indonesia. Darurat Miras Oplosan. Jakarta: Sekjen DPRI RI; 2014.

[2] Indonesian Renal Registry. $4^{\text {th }}$ Report of Indonesian Renal Registry. Jakarta: Indonesian Renal Registry; 2011.

[3] Amerika. Alcohol Alert. Rockville: NIAAA Publications Distribution Center; 2007.

[4] Van Thiel DH, Williams WD, Gavaler JS, Little JM, Estes LW, Rabin BS. Ethanol - Its Nephrotoxic Effect in the Rat. Am J Pathol. 1977; 89: $67-84$.

[5] Verhelst D, Moulin P, Haufroid V, Wittebole $X$, Jadoul M, Hantson P. Acute Renal Injury Following Methanol Poisoning: Analysis of a Case Series. Int J Toxic. 2004; 23: 267-273.

[6] Kumar V, Cotran RZ, Robbins SL. Buku Ajar Patologi. Edisi tujuh. Jakarta: Penerbit Buku Kedokteran EGC; 2012.

[7] Brzoska MM, Moniuszko-Jakoniuk J, PilatMarcinkiewikcz B, Sawicki B. Liver and 
Kawiartha, et al. Efek Minuman Keras Oplosan terhadap Perubahan Histopatologi Organ Renal....

Kidney Function and Histology in Rats Exposed to Cadmium and Ethanol. Alcohol and Alcoholism. 2001; 38(1): 2-10.

[8] Ojeda ML, Barrero MJ, Nogales F, Murillo $\mathrm{ML}$, Carreras O. Oxidative Effects of Chronic Ethanol Consumption on the Function of Hearth and Kidney: Folic Acid Supplementation. Alcohol and Alcoholism. 2012 March; 47(4): 404-412.
[9] Dinu D, Nechifor MT, Movileanu L. EthanolInduced Alteration of the Antioxidant Defense System in Rat Kidney. J Biochem Molc Toxc. 2005; 19(6): 386-395.

[10]Amalina HA, Muhartono, Fiana DN. The Influence Effect Kidney Histopathology of Magosteen Rind (Garcina mangostana L.) $40 \%$ Ethanol Extract of Rifampicin in Male Rat. Med J of Lampung University. 2013; 2(4): 91-99. 